\title{
Technological Advancement in the Media and Mobile Phone Usage among Secondary School Students in Enugu State, Nigeria
}

\author{
${ }^{1}$ Joy I. Anyanwu, ${ }^{2}$ Victoria Ogwa Adikwu, ${ }^{2}$ Catherine O. Ogwuche, \\ ${ }^{2}$ Ifeoma Keziah Ekma and ${ }^{3}$ Bernedeth N. Ezegbe \\ ${ }^{1}$ Department of Educational Foundations, University of Nigeria, Nsukka, \\ PMB 410001, Enugu State, Nigeria \\ ${ }^{2}$ Department of Counselling and Educational Psychology, University of Abuja, \\ PMB 117, Abuja, Nigeria \\ ${ }^{3}$ Department of Social Science Education, University of Nigeria, Nsukka, \\ PMB 410001, Enugu State, Nigeria, bernedeth.ezegbe@unn.edu.ng, +2348035847979
}

\begin{abstract}
The study investigated technological advancement in media and implications of mobile phone usage among secondary school students in Nsukka local government area of Enugu State. The research design used for the study was descriptive survey. Two research questions and one null hypothesis formulated guided the study. The subjects for the study comprised 3569 senior secondary school students in Nsukka local government area. A simple random sampling was used to select 357 students representing $10 \%$ of the population. The instrument for data collection was a questionnaire designed by the researchers and face validated by three experts in Faculty of Education University of Nigeria, Nsukka. Mean scores, standard deviation and student t-test were used for data analysis. Result showed that psychological implications of mobile phone usage by students include being anxious and disturbed anytime their mobile phone battery is flat, addiction to their mobile phone and snobbish attitude towards people, experiences sleep disorder, lack of concentration due to preoccupation with their mobile phone. The social implications include, watching nude pictures and videos, learning violent behaviour on the internet, less attention to peers as a result of concentration on making new friends on social networks like Facebook and 2go among others, low social and moral values and exposure to all forms of deviant behaviours through the internet. The result also revealed that no significant difference existed between psychological and social implications in terms of mobile phone usage by students. The implications of these findings were highlighted and some recommendations made.
\end{abstract}

Key words: Technological advancement, media, mobile phone, students, anxious, violent behaviour

\section{INTRODUCTION}

Technology no doubt has contributed immensely to the development of virtually all nations. This is because technology is the brain behind the usage of tools like mobile phones and cars among others for developmental purposes. Technology is the knowledge and usage of tools, techniques, crafts, systems or methods of organization in order to solve a problem or to serve some purpose (Miah and Omar, 2012). Technology according to Omeruo (2009) is an activity that forms or changes culture and imply the combination of mathematics, science and the arts to benefit life. This implies that technology is necessary and important to any nation for the achievement of desired development.

Over the past decades, technology has continued to advance and hence, contributed immensely to the development of various nations including Nigeria and Enugu State in particular. The advancement in technology has promoted the social and economic development of all nations (Miah and Omah, 2012). Such advancement of technology in the present era according to the researchers has manifested in the high level of information dissemination and enlightenment made possible by mobile technology as a part of Information and Communication Technology (ICTs). This technology advancement was introduced due to the desire for global communication and the need to bridge geographical barriers in national and international communication (Miah and Omah, 2012). Technological advancement as a concept according to Omeruo (2009) means an increasing production of tools and implements used by humans in all spheres of life to enhance the rate at which work and work-related activities are done. The concept of technological advancement

Corresponding Author: Bernedeth N. Ezegbe, Department of Social Science Education, University of Nigeria, Nsukka, PMB 410001, Enugu State, Nigeria, bernedeth.ezegbe@unn.edu.ng, +2348035847979 
refers to the improvement, developments, innovations and various changes that have taken place in both material and immaterial application of mental and physical efforts by human being in order to create values which have led to the production of more sophisticated, easily used and efficient tools, devices and utensils for achieving satisfaction of human needs in diverse works of life (Mojaye, 2015). Such improvement has been significant in the contemporary era. The researcher observed that the one area of technology advancement that is perhaps having the largest impact within developing countries is mobile phone technology and further argued that the incredible growth that mobile phone technology has experienced can be credited to the wire-free mobility that the technology offers. Besides, there are currently more mobile cellular phone subscriptions than any other form of information technology. As a result, Nigeria and the world at large are speedily embracing this mobile technology, leading to the massive use of phones, computers and media devices which can fit in people's pockets and enable them to connect to a variety of information sources. A study by Aduwa-Ogiegbaen and Iyamu (2005) on mobile phone use among residents of Benin city, Nigeria reported that apart from the traditional use of mobile phone in inter-personal communication, its use today have included other activities like learning, social interaction, sending and receiving of emails, access to internet, playing games, audio and video recording, news and many others, depending on the nature of phone in question and the age of the user.

Mobile phone use among youths has been reported to have various social, psychological and academic implications. This is based on its tendency of instigating an addiction on the user (Lee, 2004). The implication of mobile phone use can be grouped under positive and negative influences and mobile phone has potencies and enhances learning, social interaction and information dissemination (Lee, 2004). According to Morgan et al. (2011), cell phones are positive tools for keeping new college students connected to the family and friends back home. Other positive effects of mobile phone usage amongst students include easy information access, teaching tools and convenience among others.

Irrespective of the gains or rather the positive effects of mobile phone usage among secondary school students, mobile phone usage also has negative influences. Ling (2004) has reported that excessive mobile phone usage gives rise to serious social, health and educational hazard. The researcher further found out a strong correlation between excessive mobile phone usage and criminal activities such as fighting, theft use of alcohol and narcotics. Some of the negative effects of mobile phone usage according to Mojaye (2015) include, classroom distraction, reduced cognitive ability, cheating, cyberbullying and psychological disorder among others.

The psychological implications of mobile phone usage by secondary school students have been of great concern to experts and significant others. According to Mojaye (2015), students who are pre-occupied with mobile phone tend to experience psychological disorders. They are usually prone to having a higher risk of developing cornucopia or other psychological disorders including mania, paranoia, aggressive tendencies and anti-social behaviours. Tindell and Bohbander (2012) posit that some of the psychological implications of students use of mobile phone include, developing negative addiction on their phones, suffering mental retardation as they always depend on their phone for information through internet, lack of concentration, sleep disorder, always worried anytime their battery is flat and feeling unhappy without their phones among others. This has led many students astray to the extent that, they hardly do academic work in school.

There are lots of social implications of mobile phone usage by students. These social implications according to Morgan et al. (2011) include, having low social and moral values, exposure to all forms of bad behaviours, making friends on social networks like Facebook, 2go, Instagram and WhatsApp among others. They lack respect for elders, find it difficult to spend time with peers, learn violent behaviours and watch nude pictures using their mobile phones among others. Moreso, according to Mojaye (2015), mobile phones can become a serious distraction that interferes with learning. These implications need urgent attention to enable secondary school students be focused on their school work. In Nsukka Education Zone of Enugu State, it seems that secondary school students are on the negative side on mobile phone usage. This is because students more frequently use their mobile phones to visit Facebook and other social media sites for pleasure instead of academic purposes and making call. In support of the above statement Orji (2007) noted that many parents and sponsors of secondary school students are worried over their children's wrong usage of their mobile phones to Facebook and other social media sites because they are of the opinion that their children now hardly have the time to read. Orji (2007) also noted that the growing incidence of students using the mobile phone not necessarily for academic purposes but for antisocial activities is at an astonishing rate. They use the mobile phone for fraud, pornography, blackmail, racketeering and so on. Mobile phone usage has proven to be universally addictive for 
secondary school students who tend to spend considerable amounts of their time maintaining social connections, making new acquaintances and a broad base of friends during their years of study (Loving and Ochoa, 2010). This is an indication that secondary school students are using mobile phone negatively which has serious negative implication in the future. It is against this background that the researchers sought to investigate the technological advancement, implications of mobile phone usage among secondary school students in Nsukka Local Government Area of Enugu State.

Statement of the problem: It is very clear from literature and through observation that secondary school students in Nsukka Education Zone of Enugu State are using mobile phones negatively. Students use mobile phone not necessarily for academic purposes but for antisocial activities such as fraud, pornography, blackmail and racketeering among others. Students tend to spend a considerable amount of time pressing their mobile phones, maintaining social connections, making new acquaintances and a broad base of friends during their period of study instead of concentrating on their studies. If this is actually true of secondary school students in Nsukka Education Zone of Enugu State could this negative use of mobile phone have arisen due to the technological advancement of mobile phone? The researchers are worried that if students are using mobile phone negatively, it will certainly have negative implications to the national development and development of Enugu State in particular. It is against this backdrop that the present study investigated the technological advancements, implications of mobile phone usage among secondary school students in Nsukka Education Zone of Enugu State of Nigeria. The research questions posed to guide the study are:

- What are the psychological implications of mobile phone usage among secondary students?

- What are the social implications of mobile phone usage among secondary students?

Hypothesis: There is no significant difference between the psychological and social implications of students mobile phone use. The findings of this study will be beneficial to secondary school counsellors, teachers, parents and students. The findings of this study can serve as a guide, a source of insight and understanding to counsellors, teachers, parents, students and school administrators on the psychological and social implications of using mobile phone. This understanding will spur them on to be more proactive in handling the issue of phone use by students. The school administrators will be stricter in enforcing the "no phone in school" policy with the teachers monitoring students' phone activities in class while the parents will be more conscious of the programs and sites their children visit. These interventions will go a long way in reducing the psychological and social implications of phone use that may mar or distort the student's future academic life.

\section{MATERIALS AND METHODS}

The design of the study was a descriptive survey to determine the implications of mobile phone usage among secondary school students in Enugu State. The population of the study was 3569 senior secondary school students in Enugu State. The sample for this study comprised 357 respondents purposively selected from secondary schools in Nsukka Education Zone, Enugu State. The instrument used for data collection was researchers developed questionnaire put in two parts. Part one focuses on respondents personal data while part two contained ten items put in two clusters. Cluster a elicited information on psychological implications of usage of mobile phone. Cluster B addressed the social implications of mobile phone usage. The items in the clusters were placed on a four-point rating scale of Strongly Agree (SA), Agree (A), Disagree (D) and Strongly Disagree (SD). The face validity of the instrument was determined by giving the draft to three experts with one in the field of measurement and evaluation and two in guidance and counselling unit all in the Faculty of Education, University of Nigeria, Nsukka. The reliability of the instrument was determined through internal consistency measure using Cronbach alpha statistics. Thus, the instrument was administered to 20 randomly selected respondents in secondary schools in Obollo Afor Education in Enugu State. The analysis of data collected gave alpha coefficient values of 0.70 and 0.83 , respectively, for clusters A and B of part two of the instrument.

The researchers personally administered copies of the questionnaire to the respondents. Mean and standard deviation was used to answer the research questions while t-test analysis was used for the null hypothesis tested at 0.05 probability level. A criterion mean of 2.50 was used as a benchmark for decision making. Any item rated 2.50 and above was regarded as accepted while those rated below 2.50 was regarded as rejected.

\section{RESULTS AND DISCUSSION}

The results are presented in tables in line with the research questions. Data presented in Table 1 reveals the psychological implications of mobile phone usage by 


\section{J. Eng. Applied Sci., 14 (Special Issue 2): 5304-5308, 2019}

Table 1: Mean and standard deviation of psychological implications of student mobile phone usage

\begin{tabular}{llll}
\hline Item statement, students who use mobile phone & $\overline{\mathrm{X}}$ & SD & Remarks \\
Are always worried and disturbed anytime their battery is low & 2.90 & 1.15 & Agree \\
Are usually addicted to their phones and snobs people a lot & 2.57 & 1.04 & Agree \\
Experiences sleep disorder & 2.75 & 1.05 & Agree \\
Lacks concentration as they are always pre-occupied with their phones & 2.65 & 1.11 & Agree \\
Develop negative addiction to their phones & 2.58 & 1.05 & Agree \\
Grand mean & 2.59 & \\
\hline
\end{tabular}

$\mathrm{n}=357 \overline{\mathrm{X}}=2.50$ (Agree)

Table 2: Mean and standard deviation on the social implications of student's mobile phone usage

\begin{tabular}{llll}
\hline Item statement: students who use mobile phone & $\overline{\mathrm{X}}$ & SD & Remarks \\
\hline Watch nude pictures and pornographic videos using their phones & 3.80 & 1.20 & Agree \\
Learn violent behaviours from the internet & 2.50 & 1.11 & Agree \\
Make friends on social networks like Facebook and 2go & 3.06 & 1.08 & Agree \\
Are exposed to all forms of anti-social behaviours which they learn through the internet & 2.70 & 1.06 & Agree \\
Have low social and moral values & 2.56 & 1.04 & Agree \\
Grand mean & 2.92 & \\
\hline
\end{tabular}

$\mathrm{n}=357 \overline{\mathrm{X}}=2.50$ (Agree)

Table 3: t-test statistic on psychological and social implications of mobile phone usage by students

\begin{tabular}{lcccccc}
\hline Parameters & SD & No. & df & t-cal & t-crit & Decision \\
\hline Psychological implication & 2.70 & 179 & & & & \\
Social implication & 2.65 & 178 & 355 & 0.15 & 1.96 & Accepted \\
\hline
\end{tabular}

secondary school students. The result shows that 1-5 have mean scores which fall within the mean range of 2.50 which is the criterion benchmark indicating agreement of psychological implications of mobile phone usage by students. The grand mean of 2.59 , further indicates the fact that there are psychological implications for students using a mobile phone. Furthermore, the closeness of the standard deviation scores on the psychological implications of students using mobile phone indicates the less variability of the scores from the mean central tendency.

Data presented in Table 2 reveals the social implications of student's mobile phone usage. The result shows that items 5-10 have mean scores which fall within the mean range of 2.50 and above which is the criterion benchmark indicating agreement of social implications of student's use of mobile phone. The grand mean of 2.92 , further affirms the facts that there are social implications of student's use of mobile phone. Also, the closeness for all the items indicates less variability among the responses.

The data analysis in Table 3 shows that the mean for psychological implication is 2.70 while that of social implication is 2.65 . The t-test analysis to find out whether there exists a significant difference between the mean rating of psychological and social implications on student's mobile phone usage shows no significant difference. This is based on the t-calculated $(0.15)$ which is lower than the t-critical of (1.96) at 355 degrees of freedom. Based on the above result, the null hypothesis is accepted, meaning that there is no significant difference between psychological and social implications on student's mobile phone usage. From the result of data analysis, it has been found that student's usage of mobile phones has psychological implications in Enugu State. These psychological implications include, always worried and disturbed anytime their battery is flat, usually addicted to their phones and snobs people a lot an experience sleep disorder, lack concentration as they are always preoccupied with their phones and develop addiction to their phones. The findings are in agreement with Mojaye (2015) who posit that students who use mobile phone are prone to having a higher risk of developing cornucopia or psychological disorders, including mania, paranoia, aggressive tendencies and antisocial behaviours. Also, Tindell and Bohlander (2012) noted that some of the psychological implications of students usage of mobile phones include, developing a negative addiction to their phones and suffering mental retardation among others. From the findings, it is very clear that students who use mobile phones are prone to psychological disorders. This is because, at their age and level of education, they can hardly handle their emotions. The findings of this study are not surprising because secondary school students are at the stage of dependence on their parents, counsellors, teachers and significant others for decisions on their lives and cannot handle sophisticated mobile phone and its attendant negative influence.

From the result of data analysis in Table 2, it has been found that student's usage of mobile phone has social implications in Enugu State. This is reflected in their agreement to watching nude pictures and pornographic videos through their phones, learning violent behaviours on the internet, making friends on social networks like Facebook and 2go, exposure to all forms of anti-social behaviours which they learn through the internet and 
having low social and moral values. These will inadvertently affect their academic activities and consequently, their performance. The findings support earlier findings of Mojaye (2015) who noted that mobile phone usage can become a serious distraction that interferes with students learning. Furthermore, Orji (2007) posits that the growing incidence of students using the mobile phone not necessary for academic purposes but for antisocial activities is at an astonishing rate. To this effect, it is therefore clear that mobile phones have social implications for students using it. This is because students who use mobile phone to watch nude pictures and pornographic videos among others may eventually practice what they learnt on people either by coercion or force leading to dire consequences. This is not encouraging due to the fact that at their stage in education and lives, these immoral behaviours may affect their social and moral values. However, no significant difference was found between the mean scores of psychological and social implications on student's mobile phone usage. This is an indication that both attributes have implications on student's mobile phones usage.

The findings of this study have educational implications for secondary school counsellors, teachers, parents and students. This is because the findings will provide information on the psychological and social implications of student's usage of mobile phone, so that, they can guide the children and students properly on the use of mobile phone, especially, the sophisticated ones.

\section{CONCLUSION}

It is not astonishing that mobile phones usage has psychological and social implications. This is because the technological advancement of mobile phones has been generally embraced by the adolescents-both the positive and negative aspects. In view of the research findings, the following recommendations are made: counsellors, teachers, parents and students should be exposed to workshops on the proper usage of mobile phone. Parents, should not buy sophisticated phones for their children to avoid distraction and lack of concentration on their education.

\section{ACKNOWLEDGEMENT}

The researchers are grateful to the secondary school students who participated in the study.

\section{REFERENCES}

Aduwa-Ogiegbaen, S.E. and E. Iyamu, 2005. Using information and communication technology in secondary schools in Nigeria, problems and prospects. J. Educ. Technol. Soc., 8: 104-112.

Lee, J., K. Luchini, B. Michael, C. Norris and E. Soloway, 2004. More than just fun and games: Assessing the value of educational video games in the classroom. Proceedings of the International Conference on Extended Abstracts Human Factors in Computing Systems (CHI EA '04), April 24-29, 2004, ACM, Vienna, Austria, pp: 1375-1378.

Ling, R., 2004. The Mobile Connection: The Cell Phone's Impact on Society. Elsevier, San Francisco, California, USA., ISBN: 9780080518930 , Pages: 244.

Loving, M. and U. Ochoa, 2010. Facebook as a classroom solution. Overview Prev. Res., 4: 17-26.

Miah, M. and A. Omar, 2012. Technology advancement in developing countries during digital age. Intl. J. Sci. Appl. Inf. Technol., 1: 30-38.

Mojaye, E., 2015. Mobile phone usage among Nigerian University students and its impact on teaching and learning. Global J. Arts Humanities Soc. Sci., 3: 29-38.

Morgan, T.J.H., L.E. Rendell, M. Ehn, W. Hoppitt and K.N. Laland, 2011. The evolutionary basis of human social learning. Proc. R. Soc. B. Biol. Sci., 279: 653-662.

Omeruo, K., 2009. The impact of GSM mobile phones on Nigerians. EzineArticles, Nigeria, West Africa. http://webcache.googleusercontent.com/search?q= cache:ELj_JZjof-gJ:www.kiwanja.net/database/artic le/article_nigeria_impact.pdf $+\& \mathrm{~cd}=1 \& \mathrm{hl}=\mathrm{en} \& \mathrm{ct}=\mathrm{cl}$ $\mathrm{nk} \& \mathrm{gl}=\mathrm{pk} \& \mathrm{client}=$ firefox $-\mathrm{b}$

Orji, R., 2007. Reading habit among Nigerian youth. Niger. Lib. Link, 5: 93-100.

Tindell, D.R. and R.W. Bohlander, 2012. The use and abuse of cell phones and text messaging in the classroom: A survey of college students. Coll. Teach., 60: 1-9. 